\title{
Pengujian Beta Konsumsi dan Implikasinya Terhadap Imbal Hasil Saham Syariah di Indonesia dengan Mempertimbangkan Variabel Makro Ekonomi
}

\author{
Anita $^{1^{*}}$, Ratu Humaemah ${ }^{2}$, Asep Dadan Suganda ${ }^{3}$ \\ 1, 2, 3UIN Sultan Maulana Hasanuddin Banten, Indonesia \\ 1anita.febi@uinbanten.ac.id, ²ratu.humaemah@uinbanten.ac.id 3asep.dadan@uinbanten.ac.id \\ *Penulis Korespondensi
}

\begin{abstract}
This study aims to analysis the effect of beta on the yield on Islamic stocks. The research model used the Breeden model by adding macroeconomic variables as control variables in the first regression test. The sample selection used purposive sampling technique and obtained 27 active Islamic stocks listed on the JII index during 2019. The data collected are historical data, namely the monthly closing price of the JII Islamic stock index, Gross Domestic Product Data, Inflation data and SBI interest rates. The use of macroeconomic data variables is an effort to obtain an appropriate model of goodness so as to be able to produce estimates in accordance with the actual value. The beta coefficient value obtained in the first test is then carried out by the second stage regression. The results prove that there is a negative influence between consensus beta on the average yield of JII Islamic stocks. This research proves that the Consumption-Based Capital Asset Pricing Model (CCAPM) applies to the JII Islamic capital market on the Indonesia Stock Exchange.
\end{abstract}

Keywords: Consumption Beta; Return of Islamic Stock; CCAPM; Breeden

\begin{abstract}
Abstrak
Penelitian ini bertujuan untuk mengetahui pengaruh beta konsumsi terhadap imbal hasil saham syariah. Model penelitian menggunakan model Breeden dengan menambahkan variabel makroekonomi sebagai variabel kontrol pada pengujian regresi yang pertama. Pemilihan sampel menggunakan teknik purposive sampling dan diperoleh sebanyak 27 saham syariah yang aktif terdaftar pada indeks JII selama tahun 2019. Data yang dikumpulkan merupakan data historis yaitu harga penutupan bulanan indeks saham syariah JII, Data Produk Domestik Bruto, Data inflasi dan Suku bunga SBI. Penggunaan data variabel makroekonomi sebagai upaya memperoleh model Goodness of fit sehingga mampu menghasilkan estimasi yang sesuai dengan nilai aktualnya. Adapun nilai koefisien beta yang diperoleh pada pengujian pertama selanjutnya dilakukan regresi tahap kedua. Hasil penelitian membuktikan bahwa terdapat pengaruh negatif antara beta konsumsi terhadap rata-rata imbal hasil saham syariah JII. Penelitian ini membuktikan bahwa Consumption-Based Capital Asset Pricing Model (CCAPM) berlaku pada pasar modal syariah JII di Bursa Efek Indonesia.
\end{abstract}

Kata kunci: Beta Konsumsi; Imbal Hasil Saham Syariah; CCAPM; Breeden

\section{Cara Mengutip:}

Anita, Humaemah, R., Suganda, A. D. (2020). Pengujian Beta Konsumsi dan Implikasinya terhadap Imbal Hasil Saham Syariah di Indonesia dengan Mempertimbangkan Variabel Makro Ekonomi. Esensi: Jurnal Bisnis dan Manajemen. Vol. 10 (2): 181-190. DOI: https://doi.org/10.15408/ess.v10i2.18383 


\section{PENDAHULUAN}

Pertumbuhan investasi suatu negara seringkali dikaitkan dengan pertumbuhan ekonomi negaranya. Jika perekonomian suatu negara mengalami pertumbuhan dan tren yang meningkat, hal ini tentunya akan mendorong naiknya perekonomian. Kondisi ekonomi yang stabil mampu mendorong para pelaku usaha untuk mengembangkann usahanya dan menambah keyakinan para pemodal untuk menanamkan dananya pada lembaga keuangan. Implikasi dari kondisi ini akan meningkatkan kemakmuran penduduk masyarakatnya.

Menurut Samsul dalam bukunya merinci beberapa faktor makroekonomi yang secara tidak langsung dapat mempengaruhi kinerja perusahaan maupun kinerja saham diantaranya adalah: Tingkat suku bunga domestik, Kurs valuta asing, Kondisi ekonomi global, Permintaan emas, Tingkat inflasi dan Aturan perpajakan. Dengan demikian, Investor yang mampu menggunakan instrumen makroekonomi dalam memprediksi perkembangan pasar modal akan lebih siap dalam membuat keputusan investasi. (Samsul, 2006).

Sebagai negara dengan mayoritas Muslim terbesar di dunia, keberadaan instrumen investasi berbasis syariah menjadi penting. Adapun kinerja saham syariah sejak kemunculannya hingga saat ini mengalami kenaikan, yaitu telah mencapai nilai sebesar Rp 3.744.816,32 milyar, dari nilai kapitalisasi sebesar Rp 1.968.091,37 ditahun 2011. (OJK, 2020). Hal ini menjadi wahana investasi yang potensial bagi pelaku pasar modal, karena perkembangan saham syariah di Bursa Efek Indonesia memiliki kecenderungan yang meningkat. Dengan demikian dalam kondisi tersebut pengujian pada saham syariah menjadi relevan.

Berbagai faktor menjadi pertimbangan seseorang dalam mengestimasi perolehan keuntungan yang akan diperoleh. Model CAPM merupakan bagian terpenting dari penentuan portofolio optimal dengan mengestimasi beta market terhadap perubahan harga saham. Model ini berusaha menggambarkan perilaku investor terhadap kondisi pasar secara keseluruhan yang direfleksikan dengan sebuah nilai beta market meskipun perdebatan itu masih terus bergulir. Yakni, Eugene F. Fama, yang melakukan penelitian dalam rentang periode yang panjang, sejak tahun 1963 hingga 1990 lebih menyatakan bahwa dalam mengestimasi harga saham lebih mengandalkan factor fundamental, selain itu terdapat Pandasari (2012) dalam pengujiannya membuktikan beberapa rasio yaitu Return On Assets (ROA), Debt to Equity Ratio (DER), dan Book Value Per Share (BVS) memiliki pengaruh positif terhadap harga saham Begitu pula, Ivan (2018) mampu membuktikan kemampuan variabel Net Profit Margin, Cash Total Assets dan Earning Per-Share dalam memprediksi harga saham. Sehingga berdasarkan hasil pengujiannya mereka merekomendaikan penggunaan rasio fundamental perusahan daripada beta market. (F. Fama, 1992). Sejalan dengan hal itu, Scott mengakui beta cenderung berubah-ubah sepanjang waktu, sehingga apa yang diharapkan sulit untuk terjadi. (Besley, 2000).

Selanjutnya, beberapa penelitian telah dihasilkan dengan mengembangkan model CAPM. Berikut adalah beberapa penelitian yang berfokus pada membuat model estimasi return saham dengan mengembangkan capital asset pricing model (CAPM) dilakukan oleh (Merton, 1973) yang merumuskan intertemporal capital asset pricing model (ICAPM), Salah satu penelitian yang dilakukan oleh (Breeden, 1979) mampu mengembangkan consumption- based capital asset pricing model (CCAPM). Model yang dikembangkan Bredeen dengan memperhatikan asumsi bahwa risiko aset berkaitan dengan sensitivitas pada tingkat konsumsi. Besarnya 
tingkat sensitivitas imbal hasil suatu aset dengan perubahan konsumsi agregat diukur dengan beta konsumsi. (Lucas, 1978), (Douglas T. Breeden, Michael R. Gibbons, 1989), (Saleh, 2010), (Ramdhani, Angga Adityawarman; Rahardjo, 2012) serta (Effendy, 2014) yang menguji kehandalan Consumption-Based Capital Asset Pricing Model (CCAPM). Dari pengujian tersebut, ternyata hanya (Effendy, 2014) yang mampu membuktikan pengaruh beta konsumsi dalam memprediksi return dan risiko saham. Namun demikian, mereka mengakui secara intuitif bahwa model CCAPM memang baik. (Breeden, Douglas T., Litzenberger, Robert H., Jia, 2015).

Selanjutnya penelitian ini akan menguji kemampuan beta konsumsi dalam memprediksi imbal hasil saham syariah di Bursa Efek Indonesia dengan mempertimbangkan variabel pertumbuhan pendapatan, inflasi dan suku bunga. Sehingga rumusan masalah dalam penelitian adalah; bagaimana pengaruh variabel Tingkat konsumsi, pertumbuhan pendapatan, inflasi dan suku bunga terhadap tingkat imbal hasil saham syariah? dan bagaimana pengaruh beta konsumsi terhadap rata-rata imbal hasil saham syariah?

\section{METODE}

Penelitian ini mengembangkan model (Breeden, 1979) yang dinamakan model consumption-based capital asset pricing model (CCAPM). Yakni model estimasi harga saham dengan menggunakan variabel volatilitas dari tingkat konsumsi. Pada penelitian ini menambahkan variabel pertumbuhan pendapatan, inflasi dan suku bunga sebagai variabel kontrol. Sehingga model penelitiannya menjadi berikut ini:

$$
\begin{aligned}
& \mathrm{E}(\mathrm{Rit})=\alpha \mathrm{i}+\beta \mathrm{c}_{\mathrm{i}} \mathrm{c}_{\mathrm{t}}+\beta_{\mathrm{PDBi}} \mathrm{PDB}_{\mathrm{t}}+\beta_{\text {Infi }} \text { Inf }_{\mathrm{t}}+\beta_{\text {Inti }} \text { Int }+\varepsilon i t \\
& \mathrm{i} \quad=1, \ldots, 27 \\
& \text { ERit = expected imbal hasil dari portofolio sektor i pada periode } \mathrm{t} \text {. } \\
& \alpha \mathrm{i}=\text { komponen imbal hasil portofolio ssektor i yang bersifat independen } \\
& \text { ct } \quad=\text { Tingkat pertumbuhan konsumsi pada waktu } \mathrm{t} \text {. } \\
& \beta c i=\text { beta konsumsi sektor } \mathrm{i} \text {. } \\
& \beta_{\mathrm{PDBi}}=\text { koefisien pertumbuhan pendapatan nasional sektor } \mathrm{i} \text {. } \\
& \mathrm{PDB}_{\mathrm{t}}=\text { Pertumbuhan pendapatan nasional pada waktu } \mathrm{t} \text {. } \\
& \text { Inf }_{\mathrm{t}}=\text { Inflasi pada periode } \mathrm{t} \\
& \beta_{\text {Intt }}=\text { koefisien tingkat inflasi pada waktu } \mathrm{t} \\
& \text { Int }_{\mathrm{t}} \quad=\text { Suku bunga pada periode } \mathrm{t} \\
& \beta_{\text {Int }(\mathrm{t})}=\text { koefisien suku bunga pada waktu } \mathrm{t} \\
& \text { cit = disturbances atau error term portofolio sektor i pada waktu } \mathrm{t} \text {. }
\end{aligned}
$$

Data expected imbal hasil bulanan portofolio sektor (ERit) menjadi variabel dependen dan tingkat Tingkat konsumsi (ct), pertumbuhan pendapatan nasional pada waktu t $\left(\mathrm{PDB}_{\mathrm{t}}\right)^{\prime}$ Laju inflasi pada periode $t\left(\mathrm{I}_{t}\right)$ dan suku bunga pada periode $t$ (Int ${ }_{t}$ ) menjadi variabel independen. Dari persamaan (1), akan didapatkan output berupa tingkat beta konsumsi setiap portofolio sektor i ( $\beta$ ci). Perlu diperhatikan bahwa pada hasil regresi persamaan (1) akan terdapat disturbances atau error term ( $\mathrm{\varepsilon it}$ ), yang merepresentasikan faktor-faktor selain tiga variabel independen yang termasuk dalam model. Selanjutnya, koefisien $\beta$ ci yang 
diestimasi dengan regresi pada persamaan (1) diuji signifikansinya dengan menggunakan t-test statistics (t-stat). Dilanjutkan dengan pengujian regresi yang kedua, beta konsumsi diregresikan dengan rata-rata tingkat pengembalian saham (cross-section method). Adapun modelnya sebagai berikut:

$$
\mathrm{R}_{\mathrm{i}, \mathrm{t}}=\alpha_{0}+\beta^{*} \Delta \mathrm{C}_{\mathrm{i}, \mathrm{t}}+\varepsilon_{\mathrm{i},}
$$

Setelah meregresikan model persamaan (1), maka diperoleh beta konsumsi dan selanjutnya melakukan regresi dengan model persamaan (2). Adapun variabel yang digunakan dalam penelitian ini antara lain:

1) Imbal hasil saham; sebagai variabel terikat

Imbal hasil yang digunakan dalam penelitian ini dengan mengopersionalkan pergerakan harga saham syariah. Perhitungan imbal hasil saham yakni dengan membagi selisih harga penutup pefiode $t$ dengan harga penutup periode sebelumnya. Rumusnya sebagai berikut:

$$
R_{i t}=\frac{H \arg a_{-} \text {penutupan }_{t}-H \arg a_{-} \text {penutupan }_{t-1}}{H \arg a_{-} \text {penutupan }_{t-1}}
$$

2) Pertumbuhan konsumsi, sebagai variabel bebas

Konsumsi adalah setiap kegiatan memanfaatkan, menghabiskan barang (jasa) untuk memenuhi keutuhan demi menjaga kelangsungan hidup. Penelitian ini menggunakan tingkat Tingkat konsumsi, sedangkan Tingkat konsumsi menggunakan Indeks Riil Penjualan Eceran (IPE). Imbal hasil dan tingkat konsumsi diregresikan dan menghasilkan beta konsumsi. Perhitungan perubahan konsumsi $\left(\mathrm{AC}_{\mathrm{t}}\right)$, dengan rumus berikut:

$$
\Delta C_{i t}=\frac{\text { Konsumsi }_{t}-\text { Konsumsi }_{t-1}}{\text { Konsumsi }_{t-1}}
$$

Indikator makro yang digunakan dalam penelitian ini adalah pendapatan nasional, inflasi dan suku bunga.

a. Pertumbuhan Pendapatan Nasional

Data pendapatan nasional menggunakan data Produk Domestik Bruto (PDB) periode triwulan yang kemudian dilakukan interpolasi mejadi data bulanan menggunakan eviews 9.0. Selanjutkan dilakukan perhitungan laju pertumbuhan ekonomi $\left(\Delta \mathrm{Y}_{\mathrm{it}}\right)$ dengan menggunakan rumus berikut:

$$
\Delta Y_{i t}=\frac{P D B_{t}-P D B_{t-1}}{P D B_{t-1}}
$$

b. Inflasi

Data inflasi yang diproksi menggunakan IHK dari rata-rata seluruh kota besar di Indonesia.

$$
\Delta I_{i t}=\frac{I H K_{t}-I H K_{t-1}}{I H K_{t-1}}
$$


c. Suku bunga, dalam penelitian ini menggunakan data Sertifikat Bank Indonesia (SBI) tenor 1 bulanan

Untuk populasi dalam penelitian ini adalah nama saham syariah yang terdaftar di JII berjumlah 30 saham. Pemilihan sampel menggunakan teknik purposive sampling kriteria atau syarat populasi dijadikan sampel, yaitu

1. Saham syariah yang terdaftar di Jakarta Islamis Index (JII)

2. Terdaftar aktif selama tahun 2019

Berdasarkan kriteria tersebut, terdapat 3(tiga) saham yang tidak dijadikan sampel, yaitu: Bank Tabungan Pensiunan National Syariah Tbk (BTPS), Erajaya Swasembada Tbk. (ERAA) dan JAPFA Comfeed Indonesia Tbk (JPFA), sehigga jumlah saham yang dijadikan sampel hanya berjumlah 27 saham syariah dalam JII.

\section{HASIL DAN PEMBAHASAN}

Objek dalam penelitian ini adalah saham syariah di Indonesia yang terdaftar dalam Jakarta Islamic Indeks (JII) yang aktif selama 2019 yakni terdiri atas 27 saham. Periode penelitian ini dilakukan selama Januari sampai Desember 2019 dengan mengamati harga saham syariah, yang diperoleh dari website www.ojk.go.id, dengan berbagai variabel makroekonomi yang diperoleh dari website www.bps.go.id. Penelitian ini akan menganalisis pengaruh Tingkat konsumsi, pertumbuhan pendapatan, inflasi dan suku bunga terhadap imbal hasil yang diharapkan, yang dilanjutkan pengujian pengaruh beta konsumi terhadap rata-rata imbal hasil saham syariah yang terdaftar pada Jakarta Islamic Indeks tahun 2019.

Pada tabel (2) memperlihatkan bahwa selama tahun 2019 imbal hasil rata-rata tertinggi dicapai oleh sektor telekomunikasi yakni sebesar 2,33 persen, Dan minimum imbal hasil sebesar $-5,92$ persen. Angka ini jauh di bawah penurunan imbal hasil rata-rata 6 sektor usaha lainnya.

Urutan imbal hasil saham syariah pada beberapa sektor dari tertinggi sampai terendah secara berurutan yaitu: sektor telekomunikasi, sektor industri, sektor makanan, sektor konstruksi, sektor real estate, sektor pertambangan dan terakhir sektor perdagangan.

Data pertumbuhan pendapatan diperoleh dengan menggunakan perkembangan Produk Domestik Bruto (PDB) yang rilis per 3 bulan sekali. Karena kebutuhan penelitian membutuhkan data bulanan, maka peneliti melakukan interpolasi dengan bantuan program eviews 9.0. Adapun urutan pertumbuhan ekonomi dimulai dari yang tertinggi hingga terendah secara berurutan yaitu: sektor industri otomotif dan makanan (non migas 19,7 persen), sektor perdagangan (13,01 persen), sektor konstruksi (10,74 persen), sektor pertambangan (7,37 persen), sektor telekomunikasi (3,88 persen) dan sektor real estate (2,76 persen). 
Tabel 1. Hasil Uji Statistik Deskriptif Sampel

\begin{tabular}{|c|c|c|c|c|c|c|c|}
\hline & \multicolumn{7}{|c|}{ Imbal Hasil Saham Syariah per Sektor 2019} \\
\hline & Mining & Trade & Industry & Construction & Real Estate & Telecomunication & Food \\
\hline Mean & 0,001822 & 0,009467 & 0,01228 & 0,00377 & 0,00213 & 0,023362 & 0,007033 \\
\hline Median & 0,027250 & 0,010800 & 0,00100 & 0,00510 & 0,01840 & 0,030500 & 0,003550 \\
\hline Maximum & 0,343800 & 0,250000 & 0,43160 & 0,29640 & 0,13700 & 0,125000 & 0,126200 \\
\hline Minimum & 0,231200 & 0,288700 & 0,20320 & 0,23940 & 0,11660 & 0,059200 & 0,098900 \\
\hline Std. Dev. & 0,132742 & 0,121014 & 0,102025 & 0,115424 & 0,06797 & 0,054820 & 0,060557 \\
\hline Skewness & 0,414896 & 0,089600 & 0,776987 & 0,273232 & 0,0686 & 0,089235 & 0,143691 \\
\hline Kurtosis & 2.478 .978 & 2.799.181 & 5.154 .80 & 2.527 .503 & 2.784 .57 & 1.914 .618 & 2.519 .842 \\
\hline Jarque-Bera & 2.400 .042 & 0.108662 & 2.470 .30 & 1.043 .753 & 0.03262 & 1.209 .907 & 0.313141 \\
\hline Probability & 0.301188 & 0.947119 & 0.000004 & 0.593406 & 0.9838 & 0.546100 & 0.855071 \\
\hline Sum & 0.109300 & 0.340800 & 1.031 .56 & 0.180700 & 0.02550 & 0.560700 & 0.168800 \\
\hline Sum Sq. Dev. & 1.039 .611 & 0.512552 & 0.86395 & 0.626169 & 0.0508 & 0.069121 & 0.084345 \\
\hline Obs. & 60 & 36 & 84 & 48 & 12 & 24 & 24 \\
\hline
\end{tabular}

Berikut ini hasil uji stasioneritas data adalah sebagai berikut:

Tabel 2. Ringkasan Uji Stasioner

\begin{tabular}{ccc}
\hline Variabel & Prob-Level & Prob-2 $^{\text {nd }}$ Difference \\
\hline Imbal hasil Saham & 0,0000 & 0,0000 \\
Tingkat konsumsi & 0,0000 & 0,0000 \\
Pertumbuhan ekonomi & 0,0000 & 0,0000 \\
Inflasi & 0,8343 & 0,0000 \\
Suku Bunga & 1,0000 & 0,0000 \\
\hline
\end{tabular}

Berdasarkan di atas, pada uji Unit Root Test ditingkat level dari masing-masing variable menghasilkan dua variabel belum stasioner dengan menunjukkan nilai probabilitasnya > 0,05 . Oleh karena itu perlu dilakukan uji root di tingkat selanjutnya dan diperoleh nilai probabilitas dari masing-masing variabel menunjukkan nilai Probabilitas $<0,05$ yang artinya semua variabel stasioner.

Model regresi persamaan kesatu dapat ditulis sebagai berikut:

$$
Y=\beta 0+\beta 1 X 1+\beta 2 X 2+\beta 3 X 3+\beta 4 X 4+\varepsilon
$$

Keterangan:

$\mathrm{Y}=$ Imbal hasil saham syariah (Imbal hasil)

$\mathrm{X} 1$ = Tingkat konsumsi

$\mathrm{X} 2$ = Pertumbuhan ekonomi

$\mathrm{X} 3$ = Inflasi

$\mathrm{X} 4$ = Suku bunga

$\varepsilon=$ Residual/ error term 
Tabel 3. Hasil Regesi Variabel Imbal Hasil Saham

Dependent Variable: $\mathrm{D}(\mathrm{Y}, 2)$

Method: Panel Least Squares

Date: 10/12/20 Time: 15:11

Sample (adjusted): 2019M03 2019M12

Periods included: 10

Cross-sections included: 27

Total panel (balanced) observations: 270

\begin{tabular}{cclcr}
\hline Variable & Coefficient & Std. Error & t-Statistic & \multicolumn{1}{c}{ Prob. } \\
\hline D(X1,2) & 0.005575 & 0.004094 & 1.361519 & 0.1745 \\
D(X2,2) & 2.969568 & 1.137443 & 2.610741 & 0.0095 \\
D(X3,2) & -28.40470 & 5.272853 & -5.386970 & 0.0000 \\
D(X4,2) & 26.67149 & 11.18229 & 2.385154 & 0.0178 \\
C & 0.017110 & 0.013889 & 1.231873 & 0.2191 \\
\hline R-squared & 0.128245 & Mean dependent var & 0.024077 \\
Adjusted R-squared & 0.115087 & S.D. dependent var & 0.238674 \\
S.E. of regression & 0.224520 & Akaike info criterion & -0.131359 \\
Sum squared resid & 13.35845 & Schwarz criterion & -0.064722 \\
Log likelihood & 22.73346 & Hannan-Quinn criter. & -0.104600 \\
F-statistic & 9.746137 & Durbin-Watson stat & 3.001590 \\
Prob(F-statistic) & 0.000000 & & \\
\hline
\end{tabular}

Model regresi yang diperoleh dari hasil pengujian dapat ditulis sebagai berikut:

$$
Y=0.017110+0.005575 X 1+2.969568 X 2-28.40470 X 3+26.67149 X 4+\varepsilon
$$

(0.0000)

(0.0178)

Pengujian dilakukan secara panel, hal ini dimaksudkan untuk menguji keberkaitan antara variabel pertumbuhan pendapatan nasional, inflasi dan suku bunga terhadap variabel imbal hasil saham syariah. Hasil pengujian simultan memberikan nilaiProb(F-statistic) sebesar $0,0000<0,0500$ diartikan dengan menolak $\mathrm{H}_{0}$ ditolak dan menerima Ha diterima yang berarti bahwa tingkat imbal hasil saham syariah dipengaruhi oleh variabel makroekonomi (Tingkat konsumsi, pertumbuhan ekonomi, inflasi dan suku bunga), dengan demikian dapat dinyatakan bahwa variabel makroekonomi yang meliputi: Pertumbuhan ekonomi, inflasi dan suku bunga dapat dijadikan variabel kontrol dalam menguji pengaruh tingkat konsumsi terhadap tingkat imbal hasil saham syariah.

\section{Uji Statistik Per-Perusahaan}

Model regresi persamaan pertama dapat ditulis sebagai berikut:

$$
Y=\beta 0+\beta 1 X 1+\beta 2 X 2+\beta 3 X 3+\beta 4 X 4+\varepsilon
$$

Keterangan:

$\mathrm{Y}=$ Imbal hasil saham syariah (Imbal hasil)

$\mathrm{X} 1$ = Tingkat konsumsi 
$\mathrm{X} 2$ = Pertumbuhan ekonomi

$\mathrm{X} 3$ = Inflasi

$\mathrm{X} 4$ = Suku bunga

$\varepsilon=$ Residual/ error term

Pengujian regresi dilakukan untuk mencari nilai koefisien tingkat konsumsi terhadap imbal hasil saham syariah yang dikendalikan (dikontrol) oleh variabel pertumbuhan pendapatan, inflasi dan suku bunga. Dari total sampel yang berjumlah 27 saham, dilakukan analisis regresi masing-masing perusahaan.

Berdasarkan analisis regresi yang dilakukan diperoleh nilai koefisien masing-masing variabel independen. Dari 27 saham yang diujiikan terdapat 15 saham yang memberikan nilai koefisien konsumsi negatif yaitu: AKRA, ANTM, BRPT, ICBP, INCO, INDF, INDY, INTP, KLBF, LPPF, PTBA, PTPP, SMGR, WIKA DAN WSBP. Sementara terdapat 12 saham yang memberikan nilai koefisien positif yaitu: ADRO, ASII, BSDE, CPIN, CTRA, EXCL, ITMG, JSMR, SCMA, TLKM, UNTR dan UNVR.

Variabel independen yang diikutkan dalam persamaan regresi sebagai variabel kontrol adalah pertumbuhan pendapatan, inflasi dan suku bunga. Penggunaan variabel makroekonomi tersebut ditujukan untuk meningkatkan nilai $R$-squared dan meminimalisir standar error-nya. Dan sejalan dengan ilmu investasi yang meyakini bahwa imbal hasil saham dapat dipengaruhi oleh variabel makroekonomi. Berikut output persamaan model penelitian.

Tabel 4. Ringkasan Pengujian Regresi Kedua

\begin{tabular}{lllll}
\hline $\begin{array}{l}\text { Dependent Variable: } \mathbf{Y} \\
\text { Variable }\end{array}$ & Coefficient & Std. Error & t-Statistic & \multicolumn{1}{c}{ Prob. } \\
\hline $\mathrm{X}$ & -0.046894 & 0.017888 & -2.621577 & 0.0147 \\
$\mathrm{C}$ & 0.003014 & 0.004839 & 0.622942 & 0.5390 \\
\hline R-squared & 0.215629 & Mean dependent var & 0.002712 \\
Adjusted R-squared & 0.184254 & S.D. dependent var & 0.027830 \\
S.E. of regression & 0.025136 & Akaike info criterion & -4.457875 \\
Sum squared resid & 0.015795 & Schwarz criterion & -4.361887 \\
Log likelihood & 62.18131 & Hannan-Quinn criter. & -4.429333 \\
F-statistic & 6.872667 & Durbin-Watson stat & 1.231049 \\
Prob(F-statistic) & 0.014683 & & \\
\hline
\end{tabular}

Persamaan regresi hasil penelitian yaitu:

$$
\hat{R}=0,003014-0,046894 \beta c i+\varepsilon_{\text {it }}
$$

Berdasarkan hasil penelitian tersebut dapat diintrepretasikan bahwa setiap pengorbanan mengurangi tingkat konsumsi sebesar 1\% akan menambah imbal hasil saham syariah sebesar $0.0469 \%$. Nilai konstanta sebesar 0,003014 dan nilai beta konsumsinya sebesar $-0,046894$ dengan nilai standar error-nya sebesar 0,017888 dan nilai Tsignifikansi $(0.0147)<0.05$ menunjukkan bahwa menolak $\mathrm{H}_{0}$ dan menerima Ha yang artinya bahwa variabel volatilitas 
konsumsi mempengaruhi imbal hasil saham syariah JII. Hasil penelitian ini sejalan dengan penelitian (Effendy, 2014), namun bersebrangan dengan penelitian yang dilakukan (Douglas T. Breeden, Michael R. Gibbons, 1989), (Saleh, 2010) dan (Ramdhani, Angga Adityawarman; Rahardjo, 2012). Hal ini dimungkinkan karena ketersediaan data konsumsi yang masih terbatas, seperti halnya pada penelitian (Douglas T. Breeden, Michael R. Gibbons, 1989) yang mengekuivalensikan data konsumsi dengan data pengeluaran. Selanjutnya perbedaan hasil penelitian dapat pula disebabkan karena pada penelitian ini koefisien dari beta konsumsi memasukkan variabel kontrol meliputi faktor pertumbuhan pendapatan nasional, inflasi dan suku bunga, sehingga nilai pada persamaan memiliki nilai S.E yang minimal.

Dengan demikian penggunaan data konsumsi yang karakteristiknya masih tergolong umum, ternyata mampu menjadi instrumen dalam memprediksi imbal hasil saham syariah JII. Secara singkat, dapat dikatakan bahwa dalam perkembangan pasar modal syariah khususnya indeks JII terefleksi aktivitas konsumsi agregat. Hal ini sekurang-kurangnya membuktikan bahwa peran Otoritas Jasa Keuangan dan Bursa Efek Indonesia melakukan berbagai kegiatan sosialisasi dan edukasi mengenai pasar modal syariah menunjukkan hasil yang nyata.

\section{SIMPULAN}

Hasil penelitian menunjukkan bahwa variabel konsumsi skala nasional dengan menggunakan data Indeks Riil Penjualan Eceran (IPE) dapat digunakan untuk memprediksi imbal hasil saham syariah JII sebesar $21.56 \%$ dan standar error $1.79 \%$ dengan ketentuan variabel lain dianggap konstan. Penelitian ini menyakinkan bahwa model CCAPM (Breeden, 1979) berlaku pada pasar modal syariah di Bursa Efek Indonesia periode 2019.

Implikasi dari penelitian ini bahwa Pertumbuhan pendapatan, Tingkat inflasi dan Suku bunga berdampak pada perkembangan pasar modal. Hal ini sejalan dengan teori investasi yang menghubungkan variabel makroekonomi terhadap investasi saham. Dengan demikian, sebaiknya (calon) investor mengenali risiko investasi saham dengan memperhatikan variabel-variabel makroekonomi. Dan pada instrumen investasi syariah, penggunaan faktor suku bunga tetap digunakan sebagai pertimbangan opportunity cost dari beberapa pilihan investasi yang menguntungkan.

\section{PUSTAKA ACUAN}

Besley, S. E. F. (2000). Essentials of Managerial Finance (Twelfth Ed).

Breeden, Douglas T., Litzenberger, Robert H., Jia, T. (2015). Consumtion Based Asset Pricing, Part 1: Classic Theory and Test, Measurement Issues, and Limited Participation. Annual Review of Financial Economics, 7(1), 35-83.

Breeden, D. T. (1979). An Intertemporal Asset Pricing Model with Stochastic Consumtion and Opportunities. Journal of Financial Economics, 7(3), 265-296.

Douglas T. Breeden, Michael R. Gibbons, R. H. L. (1989). Empirical Test of the ConsumptionOriented CAMP. The Journal of Finance, 44(2), 231-262.

Effendy, B. C. (2014). Pengujian Metode Consumption Capital Asset Pricing Model (CCAPM) Dalam Menentukan Return dan Risiko pada Perusahaan yang Terdaftar di Indeks LQ45. Universitas Lampung. 
F. Fama, E. (1992). The Cross Section of Expected Stock Returns. The Journal of The American Finance Association, 47(2), 427-465.

Lucas, J. R. E. (1978). Asset Prices in an Exchange Economy. Econometrica, 46(6), 1429-1445.

Merton, R. C. (1973). An Intertemporal Capital Asset Pricing Model. Econometrica, 41(5), 867-887.

OJK. (2020). Kinerja Saham Syariah. https://www.ojk.go.id/id/kanal/syariah/tentang-syariah/ pages/pasar-modal-syariah.aspx

Ramdhani, Angga Adityawarman; Rahardjo, T. A. (2012). Pengujian Validitas CAPM Berorientasi Konsumsi (CCAPM) di Bursa Efek Indonesia (BEI). Journal of Capital Market and Banking, 1(2).

Saleh, D. Z. (2010). Expected Return dan Risiko Pengujian Consumption Based Capital Asset Pricing Model (CCPAM) Pasar Saham Indonesia. Integritas Jurnal Manajemen Bisnis, 3(1), 33-52.

Samsul, M. (2006). Pasar Modal dan Manajemen Portofolio. Erlangga.

Winarno, W. W. (2015). Analisis Ekonometrika dan Statistika dengan Eviews (Empat). UPP STIM YKPN. 